\title{
Phytochemical Screening and Antioxidant Property of Aqueous Murraya Koenigii (Curry Leaf) Extract
}

\author{
T. Deepika ${ }^{1}$ and C.M. Noorjahan $*^{2}$ \\ ${ }^{1}$ Ph.D. Research Scholar, P.G. \& Research Department of Zoology, JBAS College for Women (Autonomous), \\ Teynampet, Chennai - 600 018, Tamil Nadu, India. \\ E.mail Id : tdeepika15@gmail.com \\ ${ }^{* 2}$ Assistant Professor, P.G. \& Research Department of Zoology, JBAS College for Women (Autonomous), \\ Teynampet, Chennai - 600018 , Tamil Nadu, India. \\ E.mail Id : cmnoorjahan@gmail.com
}

\begin{abstract}
Murraya koenigii is commonly called as Curry Leaf, which belongs to the family Rutaceae. The leaves of Murraya koenigii was used for flavouring and spicing of food. These leaves were highly valued for their medicinal values and for characteristic aroma. There are many chemical compounds which helps the human beings in various ways. The compounds are non-nutritive and help in protection against diseases. Commonly curry leaves were accepted for various treatments in curing several disorders. Thus present study is an investigation to analyze the phytoscreening compounds present in the aqueous curry leaf and also further extended to find out its antioxidant activity using standard methods. The results of the aqueous curry leaf extract revealed the presence of phytochemical compounds such as Tannins, Saponins, Alkaloids, Proteins, Cardio glycosides and Phenols. Significant inhibitory antioxidant activity of DPPH assay was determined. Thus the $\mathrm{IC}_{50}$ value of DPPH assay was found to be $57.62 \pm 1.69 \%$ at $400 \mu \mathrm{g} / \mathrm{ml}$.
\end{abstract}

Keywords: Murraya koenigii leaves, Aqueous extract, Phytochemical Screening, Bioactive compounds, Antioxidant activity, DPPH assay.

\section{INTRODUCTION}

Humans have relied mostly on plants for nutritional and medicinal needs. Herbal plants provide most of the medicinal needs. Important herbal products include spices, herbal teas, functional foods, medicinal raw materials, essential oils, flavouring and dietary supplements [1]. The use of plants in traditional medicine is of global interest. Traditional and herbal medicines have been promoted as a source of less expensive and comprehensive medicare especially in developing countries [2]. Using plants medicines were prepared which is easily available, safe and cheaper than that of modern synthetic drugs [3]. The medicinal use of plant is due to its phytoconstituents present in them. Some of these chemicals were bioactive and contains biochemical and produce definite physiological actions in animals and humans. They are commonly called as phytochemicals or secondary metabolites which comprises of flavonoids, alkaloids, tannins, saponin, phenols, glycoside, steroids and terpenoids etc [4]. The plant Murraya koenigii (L.) belongs to family Rutaceae, which is widely distributed in almost all parts of Sri Lanka, India and other South Asian countries. It is usually cultivated in China and found in tropical and sub-tropical regions such as Nigeria, Australia etc. The leaves of Murraya koenigii is commonly called as Curry leaves from ancient times. Theses leaves used for spicing and flavouring in most of the Indian dishes. These leaves contain number of medicinal values which are beneficial for human beings. The Murraya koenigii leaves helps in relieve of nausea, vomiting, indigestion and also helps in increasing the digestive secretions [5]. The Murraya koenigii is believed to have distinctive therapeutic properties such as antidiabetic, antioxidant, antimicrobial, anti-inflammatory, anticarcinogenic and hepatoprotective properties. Murraya koenigii leaves contains the richest sources of mahanimbine, koenigine and mu online which act as carbazole alkaloids and which helps in antioxidant and anticancer properties [6].

The phytochemical compounds present in the plants may acts as a supplement for the human beings by natural antioxidants [7]. Many researchers reveals that plants contains the rich sources of antioxidants present in them. Antioxidants are the sources which helps the human body to protect themselves from free radicals during the oxidation reactions in the body metabolism [8]. Antioxidants helps in controlling and reducing the oxidative damage by dilatory or inhibiting the oxidation which is caused by Reactive Oxygen Species (ROS) which simultaneously increases the self-life and quality of the foods [9]. Murraya koenigii have strong antioxidant potential [10]. 
Thus objective of this study is to determine the phytochemical compounds of aqueous Murraya koenigii leaf extract and its efficacy of antioxidant property.

\section{MATERIALS AND METHODS}

\subsection{Collection of Plant}

From the local market the Murraya koenigii (Curry leaf) was collected and was authenticated by Prof. Jayaraman, Taxonomist, Plant Anatomy Research Centre (PARC), Chennai (Certificate No. PARC/2016/3222).

\subsection{Preparation of Plant Extract}

Using tap water and distilled water the collected fresh leaves were cleaned, shade dried for two weeks in room temperature and grinded into fine powder. The fine powder was used for the extraction using distilled water by ensuring the successive methods [11]. The mixture was drained using whatmann filter paper and the extract was further subjected for phytochemical screening and antioxidant property.

\subsection{Phytochemical screening of Aqueous Murraya koenigii leaf extract}

The aqueous Murraya koenigii leaf extract was subjected to phytochemical analysis which was carried out by following the procedures [12, 13]. Tannins, Saponins, Flavonoids, Alkaloids, Proteins, Steroids, Quinones, Terpenoids, Cardio glycosides and Phenols were estimated by ensuring the Successive methods.

Tannins: $1 \mathrm{ml}$ of aqueous Murraya koenigii leaf extract and 2-3 drops of $0.1 \%$ ferric chloride were combined and checked for the appearance of blue/black/brownish green colour.

Saponins: $1 \mathrm{ml}$ of aqueous Murraya koenigii leaf extract and $2 \mathrm{ml}$ of water were added, shaken forcefully and checked for foam appearance.

Flavonoids: $1 \mathrm{ml}$ of aqueous Murraya koenigii leaf extract, $1 \mathrm{ml}$ of concentrated hydrochloric acid and $1 \mathrm{ml}$ of magnesium chloride were combined and checked for the appearance of pink or tomato red colour.

Alkaloids: $1 \mathrm{ml}$ of aqueous Murraya koenigii leaf extract and 2-3 dops of Dragondoff reagent were combined and checked for the formation of orange red colour.

Proteins: $1 \mathrm{ml}$ of aqueous Murraya koenigii leaf extract and 2-3 drops of Bradford reagent were combined and checked for the development of blue colour.

Steroids: $1 \mathrm{ml}$ of aqueous Murraya koenigii leaf extract and $1 \mathrm{ml}$ of $10 \%$ Con. $\mathrm{H}_{2} \mathrm{SO}_{4}$ was combined and checked for the appearance of green colour.

Quinones: $1 \mathrm{ml}$ of aqueous Murraya koenigii leaf extract and 2-3 drops of aqueous ammonia were combined and checked for colour change in the aqueous layer from light brown to red, pink or violet colour.

Terpenoids: $1 \mathrm{ml}$ of aqueous Murraya koenigii leaf extract and 2-3 drops of Con. $\mathrm{H}_{2} \mathrm{SO}_{4}$ was combined and checked for the appearance of yellow colour.

Cardio glycosides: $1 \mathrm{ml}$ of aqueous Murraya koenigii leaf extract and 2-3 drops of glacial acetic acid, $0.4 \mathrm{ml}$ of Ferric chloride and 2-3 drops of Con. $\mathrm{H}_{2} \mathrm{SO}_{4}$ were added. The solution was checked for the appearance of brown coloured ring.

Phenols: $1 \mathrm{ml}$ of aqueous Murraya koenigii leaf extract, $2 \mathrm{ml}$ of distilled water and 2-3 drops of Ferric chloride were combined and checked for the formation of green or blue colour.

\subsection{Determination of Antioxidant Activity of Aqueous Murraya koenigii leaf extract}

\subsubsection{2, 2- diphenyl-1-picrylhydrazyl (DPPH)}

Antioxidant activity of aqueous Murraya koenigii leaf extract on the basis of the scavenging property of the 2, 2-diphenyl-1-picrylhydrazyl (DPPH) free stable radical was obtained by following the procedure [14].

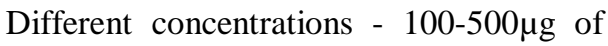
$1 \mathrm{ml}$ aqueous Murraya koenigii leaf extract were combined with $1 \mathrm{ml}$ of $0.004 \%$ methanol solution of DPPH. The mixture was oscillated well and permitted for 30 minutes undisturbed at normal room temperature in the dark. The lowering of the DPPH radical was obtained by reading the transmittance at $517 \mathrm{~nm}$. The same methodology was carried out for the control. $\mathrm{IC}_{50}$ value were calculated for the different concentrations of aqueous Murraya koenigii leaf extract from the graph by plotting inhibition percentage on $\mathrm{X}$ axis against concentration of the sample on $\mathrm{Y}$ axis. For Positive control, Ascorbic acid was used. The DPPH free radical scavenging property was estimated as follows:

$\%$ Antioxidant (Absorbance at bank)-(Absorbance at te

Activity $=$ (Absorbance at bank) 


\section{STATISTICAL ANALYSIS}

Data obtained from the experiment was expressed in the pattern as Mean and Standard Deviation.

\section{RESULTS AND DISCUSSION}

In the present investigation, phytochemical constituents and anti-oxidant activity of aqueous Murraya koenigii (Curry leaf) extract were determined.

\subsection{Phytochemical screening of aqueous leaf extract of Murraya koenigii}

The presence of secondary metabolites is responsible for therapeutic potential of plants. These include Tannins, Saponins, Flavonoids, Alkaloids, Proteins, Steroids, Quinones, Terpenoids, Cardio glycosides and Phenols. Phytochemical screening provides the information about these secondary metabolites.

The results of phytochemical screening of aqueous Murraya koenigii (Curry leaf) extract showed the presence of Tannins, Saponins, Alkaloids, Proteins, Cardio glycosides and Phenol. The results were detailed in Table -1 and Plate 1(A and B).

Table 1: Phytochemical screening of aqueous Murraya koenigii leaf extract

\begin{tabular}{|r|c|c|}
\hline S.No. & Constituents & Presence / Absence \\
\hline 1. & Tannins & + \\
\hline 2. & Saponins & + \\
\hline 3. & Flavonoids & -- \\
\hline $\mathbf{4 .}$ & Alkaloids & + \\
\hline $\mathbf{5 .}$ & Proteins & + \\
\hline 6. & Steroids & -- \\
\hline $\mathbf{7 .}$ & Quinones & -- \\
\hline
\end{tabular}

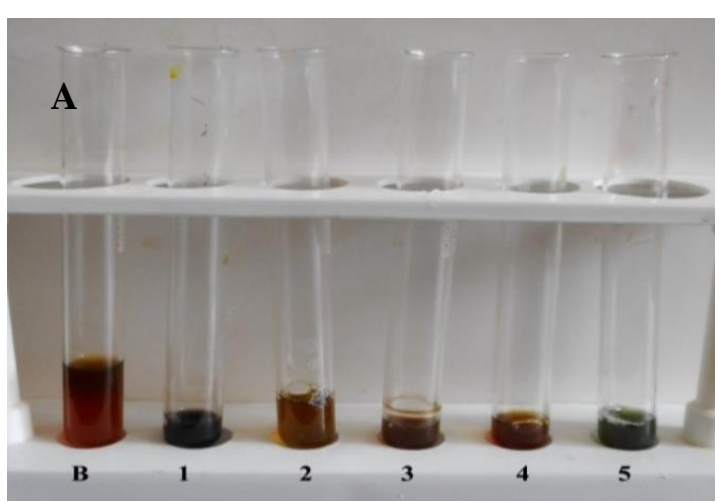

\begin{tabular}{|c|c|c|}
\hline 8. & Terpenoids & -- \\
\hline 9. & Cardio glycosides & + \\
\hline 10. & Phenols & + \\
\hline
\end{tabular}

Plate - 1(A and B) : Phytochemical screening of aqueous Murraya koenigii leaf extract

The therapeutic value of medicinal plants lies in the various chemical compounds processed in them. The bioactive compounds of plant extract are attributed to phytochemical compounds of plants. If the plants rich in tannin compound they have high potent in controlling the bacteria, due to this character they allow to react with the proteins to form stable water soluble compounds hence, it kills the bacterial by directly damaging its cell membrane [15]. Flavonoids are the dominant group of phenolic compounds which is reported by their antiviral [16], antimicrobial [17] and spasmolytic [18] properties. From plants, Alkaloids were isolated which was commonly found to have

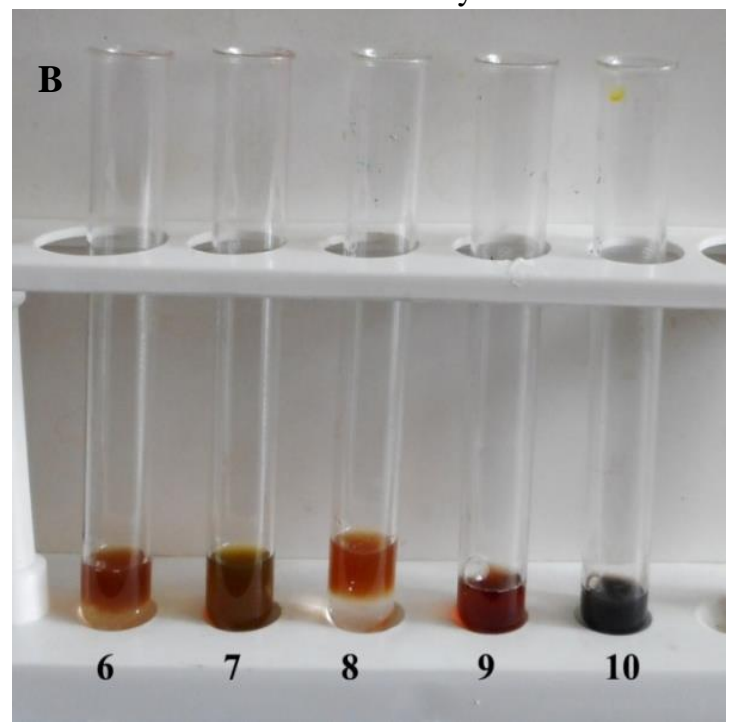

antimicrobial properties [19]. Saponins also possess hypocholesterolemic and antidiabetic properties [20]. Steroids and Triterpenoids are known to have palliative properties [21]. Hence from the above results of phytoscreening of aqueous Murraya koenigii leaf extract declared the presence of Tannins, Saponins. Alkaloids, Proteins, Cardioglycosides and Phenols in the aqueous Murraya koenigii (Curry leaf) extract. Similar results were obtained [22, 23, 10, 24].

\subsection{Antioxidant Property of Aqueous Murraya} koenigii leaf extract

\subsubsection{2, 2- diphenyl-1-picrylhydrazyl (DPPH) Radical Scavenging Assay}

Antioxidant compounds may function as free radical scavengers, initiator of the complexes 
of pro-oxidant metals, quencher of singlet oxygen formation and reduced agents [25].

The DPPH radical scavenging assay has been widely used to analyze the prospective of the compounds such as free radical scavengers of the hydrogen donors and used to examine the antioxidant activity of plant extract. Phenolic compounds present in plants act as antioxidant or free radical scavengers due to their $\mathrm{OH}$ groups, which devoted directly to the antioxidant action [26].

Hence, the significance of search for natural anti-oxidants has highlighted in the recent years [27]. Therefore, the present study is an attempt to examine the ability of the aqueous Murraya koenigii (Curry leaf) extract for antioxidant free radical DPPH scavenging activity.

The results of DPPH free radical scavenging assay of aqueous Murraya koenigii leaf extract were depicted in Table -2 and Figure -1 .

The results of DPPH free radical scavenging assay of aqueous Murraya koenigii (Curry leaf) extract were confirmed the DPPH free radical scavenging antioxidant activity. The inhibitory effect of aqueous Murraya koenigii leaf extract ranged from $100 \mu \mathrm{g} / \mathrm{ml}$ to $500 \mu \mathrm{g} / \mathrm{ml}$ concentration. From the results obtained (Table - 2 and Figure - 1) it was observed that as there is increase in sample concentration there is increase in the percentage of inhibition also.

Table - 2: DPPH Scavenging Assay of aqueous leaf extract of Murraya koenigii

\begin{tabular}{|c|c|c|}
\hline $\begin{array}{c}\text { Concentra } \\
\text { tions of the } \\
\text { sample } \\
(\boldsymbol{\mu g} / \mathbf{m l})\end{array}$ & \multicolumn{2}{|c|}{$\begin{array}{c}\text { \% of inhibition of samples at } \\
\text { different concentrations }\end{array}$} \\
\cline { 2 - 3 } & $\begin{array}{c}\text { Standard } \\
\text { Ascorbic Acid }\end{array}$ & $\begin{array}{c}\text { Aqueous Murraya } \\
\text { koenigii leaf } \\
\text { extract }\end{array}$ \\
\hline 100 & $85.76 \pm 0.80$ & $15.81 \pm 2.59$ \\
\hline 200 & $90.5 \pm 0.5$ & $38.41 \pm 2.58$ \\
\hline 300 & $91.53 \pm 0.50$ & $45.19 \pm 0.98$ \\
\hline 400 & $95.53 \pm 0.61$ & $57.62 \pm 1.69$ \\
\hline 500 & $98.26 \pm 0.25$ & $68.64 \pm 1.20$ \\
\hline \multicolumn{3}{|c|}{$\begin{array}{c}\text { The values were represented as } \\
\text { Mean } \pm \text { Standard deviation }\end{array}$} \\
\hline
\end{tabular}

Figure - 1 : DPPH scavenging assay of aqueous Murraya koenigii leaf extract

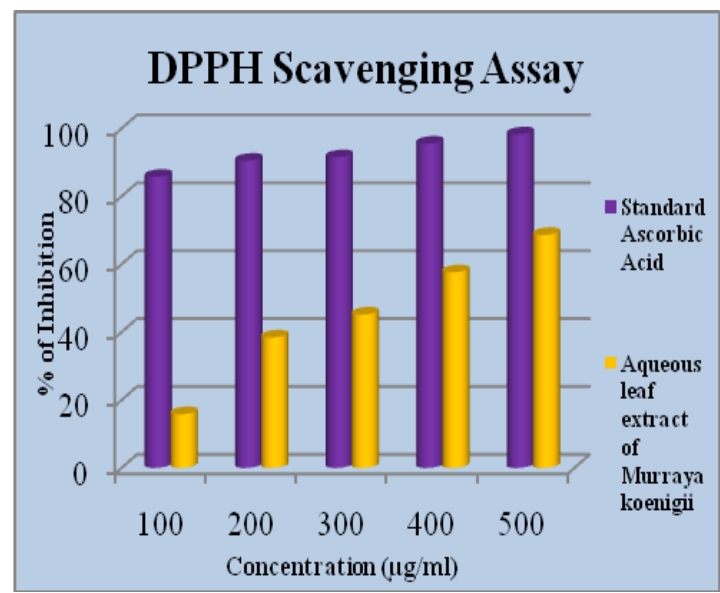

As seen from the Table - 2 and Figure - 1, DPPH free radical scavenging activity of aqueous Murraya koenigii leaf extract revealed the highest percentage of inhibitory activity in aqueous Murraya koenigii leaf extract $(68.64 \pm 1.20 \%)$ when compared with standard ascorbic acid $(98.26 \pm 0.25 \%)$ at $500 \mu \mathrm{g} / \mathrm{ml}$ concentration. The least percentage of inhibition $(15.81 \pm 2.59 \%)$ was recorded at $100 \mu \mathrm{g} / \mathrm{ml}$ concentration. Thus from the conclusion of the study revealed that the percentage of inhibitory effect increases with the increase in concentration of the sample. The aqueous Murraya koenigii (Curry leaf) extract exhibited significant antioxidant property and the values were declared as Mean \pm Standard deviation. The analysis of the above study is in agreement with the studies $[10,28$, 29].

\section{CONCLUSION}

Thus, from the results of the above study, it can be declared that the phytochemical screening and antioxidant activity of aqueous Murraya koenigii leaf extract has significant therapeutic properties. Murraya koenigii (Curry leaf) contains functional ingredients that can be implemented in pharmaceutical industries so as to develop drugs to cure many diseases.

\section{REFERENCES}

[1] Harish, KH.; Pandith, A.; Shruthi, SD. (2015): A review on Murraya koenigii: multi-potential medicinal plant. Asian Journal of Pharmaceutical and Clinical Research, 5(4), pp: 5-14.

[2] Ujuwundu, CO.; Okafor, OE.; Agha, NC.; Nwaogu, LA.; Igwe, KO.; Igwe, CU. (2010): Phytochemical and chemical composition of Combretum zenteri leaves. Journal of Medicinal Plant Research, 4(10), pp: 965-968.

[3] Kaur, G.; Daftardar, S.; Barve.; KH. (2014): Modifying antiinflammatory effect of Diclofenac with Murraya koenigii: Recent 
patent on inflammation and allergy. Drug Discovery, 8(1), pp: 77-81.

[4] Summan, S.; More, PK.; Sandhya, MM. (2014): Curry leaves (Murraya koenigii Linn Spreng) a miracle plant. Indian Journal of Science Research, 4(1), pp: 46-52.

[5] Chevallier, A. (1996): The Encyclopedia of Medicinal Plants. London/New York/Stuttgart/Moscow: Dorling Kindersley, 366.

[6] Kirupa, SLS.; Kariitha, R. (2015): Anti-oxidant enhancing property of curry leaf powder $M$. koenigii in type II Diabetes mellitus. Intl. Journal of Pharmacy and Biosciences, 6(1), pp: 507-514.

[7] Boots, AW.; Haenen, GR.; Bast, A. (2008): Health effects of quercetin: From antioxidant to nutraceutical. Eur. J. Pharmacol., 585, pp: 325337.

[8] Farasat, M.; Khavari-Nejad, RA.; Nabavi, SMB.; Namjooyan, F. (2014): Antioxidant activity, Total Phenolics and Flavonoid contents of some edible Green Seaweeds from Northern Coasts of the Persian Gulf. Iran Journal of Pharma Res., 13(1), pp: 163-170.

[9] Ruan, ZP.; Zhang, LL.; Lin, YM. (2008): Evaluation of the antioxidant activity of Syzygium Cumini leaves. Molecules, 13, pp: 2545-2556.

[10] Aju, BY.; Rajalakshmi, R.; Mini, S. (2017): Evaluation of antioxidant activity of Murraya koenigii (L.) Spreng using different invitro methods. Journal of Pharmacognosy and Phytochemistry, 6(4), pp: 939-942.

[11] Harborne, JB. (1973): Phytochemical methods: A guide to modern techniques of plant analysis. Chapman and Hall Ltd. London, pp: 49-279.

[12] Harborone, JB. (1998): Textbook of Phytochemical Methods. A Guide to Modern Techniques of Plant Analysis. Chapman and Hall Ltd, London, Fifth Edition, pp: 21-72.

[13] Kokate, CK. (1958): Practical Pharmacognosy, Vallabh Prakashan, Pune, Fourth Edition, pp: 107-129.

[14] Blois, MS. (1958): Antioxidant determination by the use of a stable free radical. Nature, 181, pp: 1199-1200.

[15] Mohamed Sham Shihabudeen, H.; Hansi Priscilla, D.; Kavitha, T. (2010): Antimicrobial activity and phytochemical analysis of selected Indian folk medicinal plants. Int. J. of Pharma Sci Res., 1(10), pp: 430-434.

[16] Mehrangiz, KK.; Seyed, AE.; Masoud, SG.; Esmaeel, AS.; Amirhossein, S. (2011): Antiviral activities of aerial subsets of Artemisia species against Herpes Simplex Virus type 1 (HSV1) invitro. Asian Biomed, pp: 430434.

[17] Maria lysete, AB.; Maria Raquel, FL. (2009): Studies on the antimicrobial activity and brine shrimp toxicity of $Z$. tuberculosa extracts and their main constituents. Annals of Clil. Microb. Antimic., pp: 8:16.

[18] Julianeli, TDL.; Jackson, RGS.; Kelly, S.; Ana Silvia, SC. (2011): Selective spasmolytic effect of a new furanoflavoquinone derivative from diplotropin on guinea-pig trachea. J. Chem. Pharm. Res., 3(1), pp: 249-258.

[19] Ahmed el-HM, Nour, BY.; Mohammed, YG.; Khalid, HS. (2010): Antiplasmodial activity of some medicinal plants used in Sudanese folkmedicine. Env. Health Insts., 4(4), pp: 1-6.

[20] Rupasinghe, HP.; Jackson, CJ.; Poysa, V.; Di Berardo, C.; Bewley, JD.; Jenkinson, J. (2003): Soyasapogenol A and B Distribution in Soybean (Glycine max L. Merr.) in relation to seed physiology, genetic variability and growing location. J. Agric. Food Chem., 51, pp: 5888-5894.

[21] Malairajan, P.; Gopalakrishnan, G.; Narasimhan, S.; Veni, KVK. (2006): Analgesic activity of some Indian medicinal plants. J. Ethnopharmacol., 106, pp: 425-428.

[22] Sharma, P.; Vidyasagar, G.; Bhandari, A.; Singh, S.; Ghul, S.; Agarwal, A.; Goyal, S.; Panwar, M. (2011): Antiulcer activity of leaves extract of Murraya koenigii in experimentally induced ulcer in rats. J. Pharm., 2, pp: 818-824.

[23] Prabakaran, M.; Sangeetha, P.; Ranganatha, V.; Punniyamoorthy, N.; Ramesh Kumar, K. (2013): Phytochemical screening and antibacterial activity of Murraya koenigii (L.) against Escherichia coli, Klebsiella pneumoniae and Staphylococcus aureus. International Journal of Pure and Applied Zoology, 1(4), pp: 289-294.

[24] Rajesh Singh Tomar, Sharmistha Banerjee, Shuchi Kaushik, (2017): Assessment of antioxidant activity of leaves of Murraya koenigii extracts and its comparative efficacy analysis in different solvents. J. Pharm. Sci. and Res., 9(3), pp: 288-291.

[25] Ji-young Lee, Woo-Ik Hwang, Seung-Taik Limm, (2004): Antioxidant and anticancer activities of organic extracts from Platycodon grandiflorum A. De Candolle roots. J. Ethanopharmacol., 93(2-3), pp: 409-415.

[26] Dejan Orcic, Z.; Neda Mimica-Dukic, M.; Marina Franciskovic, M.; Slobodan Petrovic, S.; Emilija Jovin, D. (2011): Antioxidant activity relationship of phenolic compounds in Hypericum perforatunm L. Chem. Cent. J., 5:34. 
International Journal of Research in Advent Technology, Vol.7, No.2, February 2019

E-ISSN: 2321-9637

Available online at www.ijrat.org

[27] Kaufmann, SH.; Hengartner, MO. (2001): Programmed cell death: alive and well in the new millennium. Trends in cell biology, 11, pp: 526-534.

[28] Indu sasidharan, Nirmala Menon, A. (2011): Effects of temperature and solvent on antioxidant properties of Curry leaf (Murraya koenigii L.). Journal of Food Sci. Technol., 48(3), pp: 366-370.

[29] Rajnikant, Saima Kumar, Amit Chattree, (2015): Antioxidant and Antifungal potential of Murraya koenigii leaves extracts (Crude) and essential oil. Chemical Science Transactions, 4(1), pp: 222-226. 